\title{
Stem Cells and Their Role in Renal Ischaemia Reperfusion Injury
}

\author{
Atul Bagul $^{\mathrm{a}} \quad$ Jodie H. Frost ${ }^{\mathrm{b}}$ Martin Drage ${ }^{\mathrm{a}}$ \\ a'Department of Transplantation, MRC Centre for Transplantation, Guys and St. Thomas' NHS Foundation Trust, \\ London, and ${ }^{b}$ Department of Surgery, John Radcliffe Hospital, Oxford University Hospitals, Oxford, UK
}

\section{Key Words}

Stem cells • Ischaemia reperfusion injury • Acute renal injury $\cdot$ Transplantation

\begin{abstract}
Background: Ischaemia-reperfusion injury (IRI) remains one of the leading causes of acute kidney injury (AKI). IRI is an underlying multifactorial pathophysiological process which affects the outcome in both native and transplanted patients. The high morbidity and mortality associated with IRI/ $\mathrm{AKI}$ and disappointing results from current available clinical therapeutic approaches prompt further research. Stem cells (SC) are undifferentiated cells that can undergo both renewal and differentiation into one or more cell types which can possibly ameliorate IRI. Aim: To carry out a detailed literature analysis and construct a comprehensive literature review addressing the role of SC in AKI secondary to IRI. Methods: Evidence favouring the role of SC in renal IRI and evidence showing no benefits of SC in renal IRI are the two main aspects to be studied. The search strategy was based on an extensive search addressing MESH terms and free text terms. Results: The majority of studies in the field of renal IRI and stem cell therapy show substantial benefits. Conclusions: Studies were mostly conducted in small animal models, thus underscoring the need for further pre-clinical studies in larg-
\end{abstract}

er animal models, and results should be taken with caution. SC therapy may be promising though controversy exists in the exact mechanism. Thorough scientific exploration is required to assess mechanism, safety profile, reproducibility and methods to monitor administered SC.

Copyright $\odot 2012$ S. Karger AG, Basel

\section{Introduction}

Ischaemia-reperfusion injury (IRI) remains one of the leading causes of acute kidney injury (AKI) in both native and transplanted kidneys $[1,2]$. IRI is an underlying multifactorial pathophysiological process which affects the outcome in many clinical situations, in particular transplantation $[3,4]$. Transplantation, the therapy for ESRD, is associated with several deficiencies: lack of suitable organs, immunosuppression, surgical morbidity and poorer outcomes associated with use of marginal organs [5] [extended-criteria donors (ECDs) and donors after circulatory death (DCDs)] and patients waiting longer on the waiting list [6-8]. The process of IRI is accelerated in recipients receiving organs from ECDs and DCDs. This reflects in increased rates of delayed graft function and primary non-function as a consequence of the associated ischaemia especially the prolonged warm ischaemic in-

\section{KARGER \\ Fax +4161306 1234 \\ E-Mail karger@karger.ch}

www.karger.com (c) 2012 S. Karger AG, Basel

0250-8095/13/0371-0016\$38.00/0

Accessible online at:

www.karger.com/ajn
Mr. Atul Bagul

Department of Transplantation

Guys and St. Thomas' NHS Foundation Trust

London SE1 9RT (UK)

E-Mail atulbagul@yahoo.com 
sult sustained during organ retrieval and added cold storage time $[4,9-10]$. In the native kidney situation, AKI affects $7-10 \%$ of all hospitalised patients and can be associated with a mortality rate of $35-40 \%$ for inpatients and $75 \%$ for patients with sepsis-associated renal failure [11]. The current management for AKI is non-specific and associated with limited supportive care; thus, the need for more novel approaches is warranted [12].

The pathophysiological process of AKI following IRI leads to functional and structural changes that are centred around the proximal tubule cells and endothelium [13]. The pathological events involve disruption of the actin cytoskeleton, alteration in adenine nucleotide metabolism and intracellular calcium, loss of cell-cell/cell-ECM attachments, generation of reactive oxygen molecules and inflammatory responses following activation of endothelium leading to recruitment and infiltration of effector cells and upregulation of apoptosis [14-19]. The kidney can recover remarkably by subsequent events involving cell de-differentiation and proliferation. This is achieved by participation of integrins and cell adhesion molecules which are regulators of migration, differentiation and proliferation. The local release of growth factors like hepatic growth factor (HGF), insulin-like growth factor (IGF), chemokines and cytokines coordinate this cell proliferation [19-21]. Repolarisation and differentiation can be brought about by other factors like neural cell adhesion molecule and osteopontin [13].

Stem cells (SC) are undifferentiated cells defined by their ability for self-renewal and the capacity for multilineage differentiation [22-24]. The mechanisms of action for stem cell therapy are under debate. Current thoughts as to how they might ameliorate renal IRI [2531] are as follows: (1) transdifferentiation/de-differentiation/homing of SC; (2) paracrine or endocrine effects of grafted SC; (3) role of resident stem/progenitor cell expansion and proliferation.

Based on their expression of cell surface markers, transcription factors and cytokines, a stem cell can be categorised as being either cytological or functional [23].

Bone marrow-derived SC (BMSC) can be classified as follows: (1) haematopoietic SC (HSC), which give rise to all differentiated blood cells [31]; (2) mesenchymal SC (MSC)/marrow stromal cells which differentiate into MSC like chondrocytes, osteocytes and adipocytes [23, $24,31]$.

Additionally, adult SC of various types have been identified in tissues like intestine, adipose, skeletal muscle, myocardium and renal tissue [32,33]. Adult SC from skeletal muscle contain unipotent satellite cells which fuse and differentiate into multinucleated myotubes [34, 35], and have been shown to give rise to cells of different lineages $[36,37]$. These various SC have been shown in various experimental studies to alter the various IRI responses described above and possibly ameliorate the functional parameters by accelerating regeneration of proximal tubular cells. SC can lead to inhibition of release of various proinflammatory cytokines and secrete various trophic growth factors that promote angiogenesis, mitogenesis and proliferation while reducing apoptosis [38], attenuate inflammation and initiate repair [39].

The emerging field of regenerative medicine is progressing rapidly and is supported by a large number of studies demonstrating the capacity of SC to substitute for the damaged or lost differentiated cells in various organs and tissues [40-43]. There is considerable debate as to whether the effect of these cells is due to transdifferentiation or their paracrine properties [25-31, 44-49]. SC therapy may have the potential to be developed into the novel therapeutic approach to address AKI.

\section{Aims}

The aim of this review was to carry out a detailed literature analysis and construct a comprehensive literature review addressing the role of SC in AKI secondary to renal IRI. This in-depth document will thus address in detail the following two main aspects: (1) evidence favouring the role of SC in renal IRI; (2) evidence showing no benefits of SC in renal IRI.

\section{Methods and Search Strategy}

An extensive search of MEDLINE (PubMed - 1966-2012), The Cochrane Central Register of Controlled Trials, EMBASE (1974-2010), The Database of Abstracts of Reviews of Effects, Health Technology Assessment Database was performed to identify relevant studies (fig. 1).

The search strategy was based on the following terms: MESH terms - Reperfusion Injury, Acute Kidney Injury, Stem Cells, Adult Stem Cells (ASC), Embryonic Stem Cells (ESC), Mesenchymal Stem Cells, Endothelial Cells (ECs), Hematopoietic Stem Cells, Tissue Therapy, Kidney Transplantation, Delayed Graft Function, Humans, Cell Transplantation; free text terms - Renal Ischaemia Reperfusion Injury, Adipose Tissue-Derived Stem Cells, Adipose Tissue-Derived Stem and Regenerative Cells (ADRC), Endothelial Progenitor Cells (EPCs), Neural Precursor Cells (NPC), Bone Marrow-Derived Stem Cells, Bone Marrow Mesenchymal Stem Cells (BM-MSC), Bone Marrow-Derived Endothelial Progenitor Cells, Granulation Tissue Stem Cells (GTSC), Autologous Mesenchymal Stem Cells, Cell Therapy, Transdifferentiation of Stem Cells, Paracrine Action of Stem Cells. 
The search had no date restrictions and included experimental, clinical, review and editorial articles in the English literature. The search generated 175 articles, out which 53 were deemed not relevant. The 122 referenced documents include 70 experimental, 13 clinical, 36 reviews and 3 editorial articles.

\section{Evidence Favouring SC in Renal IRI}

\section{Transdifferentiation/De-Differentation/Homing of SC} (table 1)

Brodsky et al. [50] observed that during renal IRI, endothelial cells were severely damaged, and transplantation of adult human endothelial cells into an athymic nude rat which was subjected to renal ischaemia resulted in protection of kidney against injury and dysfunction. The group in 2004 showed that skeletal muscle provides a rich source of skeletal muscle-derived SC and delineated protocols for their in vitro expansion and differentiation along the endothelial lineage, thereby demonstrating engraftment of transplanted cells into renal microvasculature [32]. Lin et al. [31] in a ROSA26 mouse model showed that HSC were able to differentiate into renal tubular cells and augment renal function after renal IRI. The published data showed that on polymerase chain reaction analysis, the presence of male-specific Sry gene and $\mathrm{Y}$ chromosome fluorescent in situ hybridisation confirmed the presence of male-derived cells in kidneys of female recipients, thus supporting the homing/de-differentiation hypothesis. Similarly, Jiang et al. [51] in the rat model showed improvement of IRI, and the beneficial effects were due to differentiation of bone marrow MSCs (BM-MSC) into the phenotype of damaged tissue cells where they were able to demonstrate homing of BM-MSC with a high engraftment level of nearly $20 \%$.

\section{Paracrine/Endocrine Effects of Grafted SC (table 1)}

In contrast, Togel et al. [23, 52] demonstrated in a rat IRI model that considerable significant renoprotection was obtained with multipotent MSCs, though none of the administered MSCs had differentiated into tubular or endothelial cell phenotypes. The beneficial effects they concluded were primarily mediated via a complex paracrine action. This was through amelioration of inflammatory, vascular and apoptotic/necrotic manifestations of renal IRI. A significant reduction of proinflammatory cytokines like interleukin-1- $\beta$ (IL-1 $\beta$ ), tumour necrosis factor- $\alpha$ (TNF- $\alpha$ ), interferon- $\gamma($ IFN- $\gamma$ ) and inducible nitric oxide synthase, as well as an upregulation of anti-inflammatory cytokines like IL-10, basic fibroblast growth factor, transforming growth factor- $\alpha$ and B-cell lymphoma

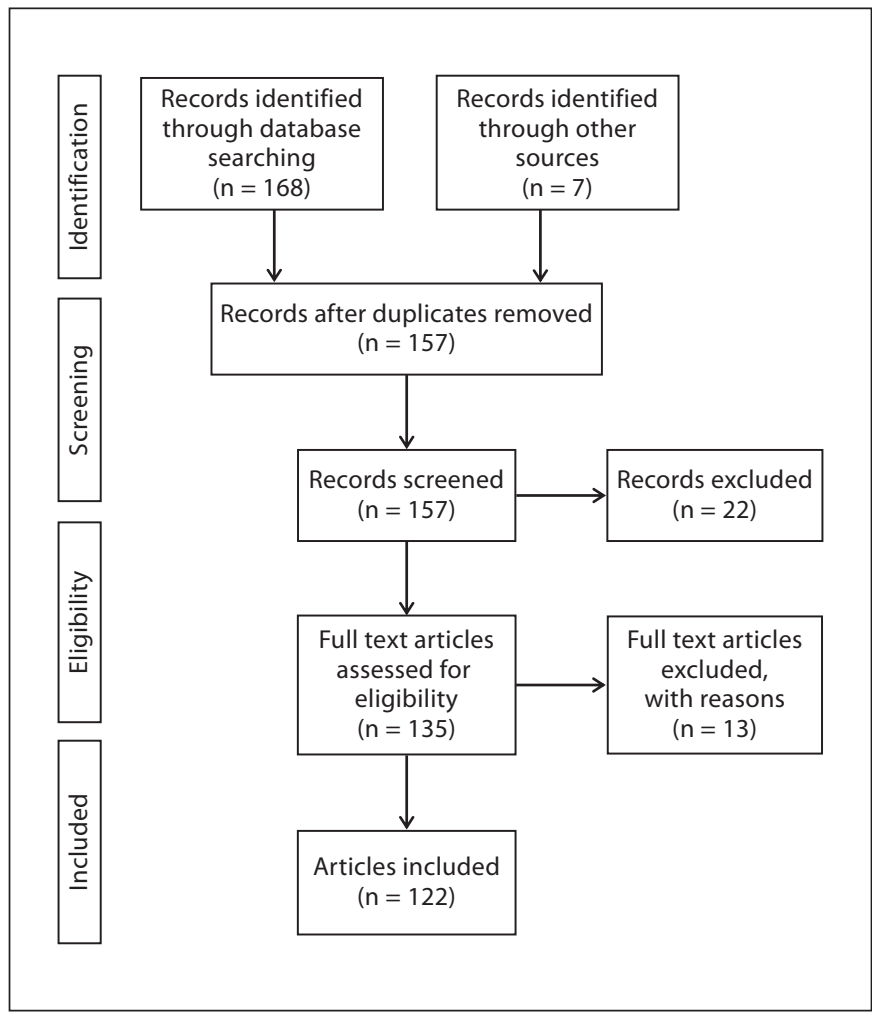

Fig. 1. PRISMA flow diagram.

(2Bcl-2) was demonstrated. Similarly, Semedo et al. [53] demonstrated an anti-inflammatory pattern in MSCtreated rats, where higher levels of anti-inflammatory cytokines (IL-4) and reduced levels of proinflammatory cytokine IL-1 $\beta$ were demonstrated. Recently, Patel et al. [54] demonstrated in an IRI rat model the beneficial paracrine role of GTSC. They showed that GTSC treatment led to a 2 - to 8 -fold increased expression of growth factors (fibroblast growth factor 2, HGF, IGF-1, vascular endothelial growth factor, VEGF) and anti-inflammatory factors (IL-4, IL-10). The authors thereby concluded that foreign body-induced GTSC ameliorate IRI in rats, and may form an important source of SC because of easier accessibility and abundance compared to SC from bone marrow [54].

IRI leading to renal tissue damage is associated with Th (T helper)-1-induced immune responses. Thus, MSC have an ability to deviate the Th1/Th2 response which is seen following IRI, supporting the paracrine function of SC [53]. Semedo et al. demonstrated that the immunemodulatory effects of MSC occur at a very early time point, thus changing the inflammatory profile towards a 
Table 1. Studies highlighting benefits of SC therapy in small animal models

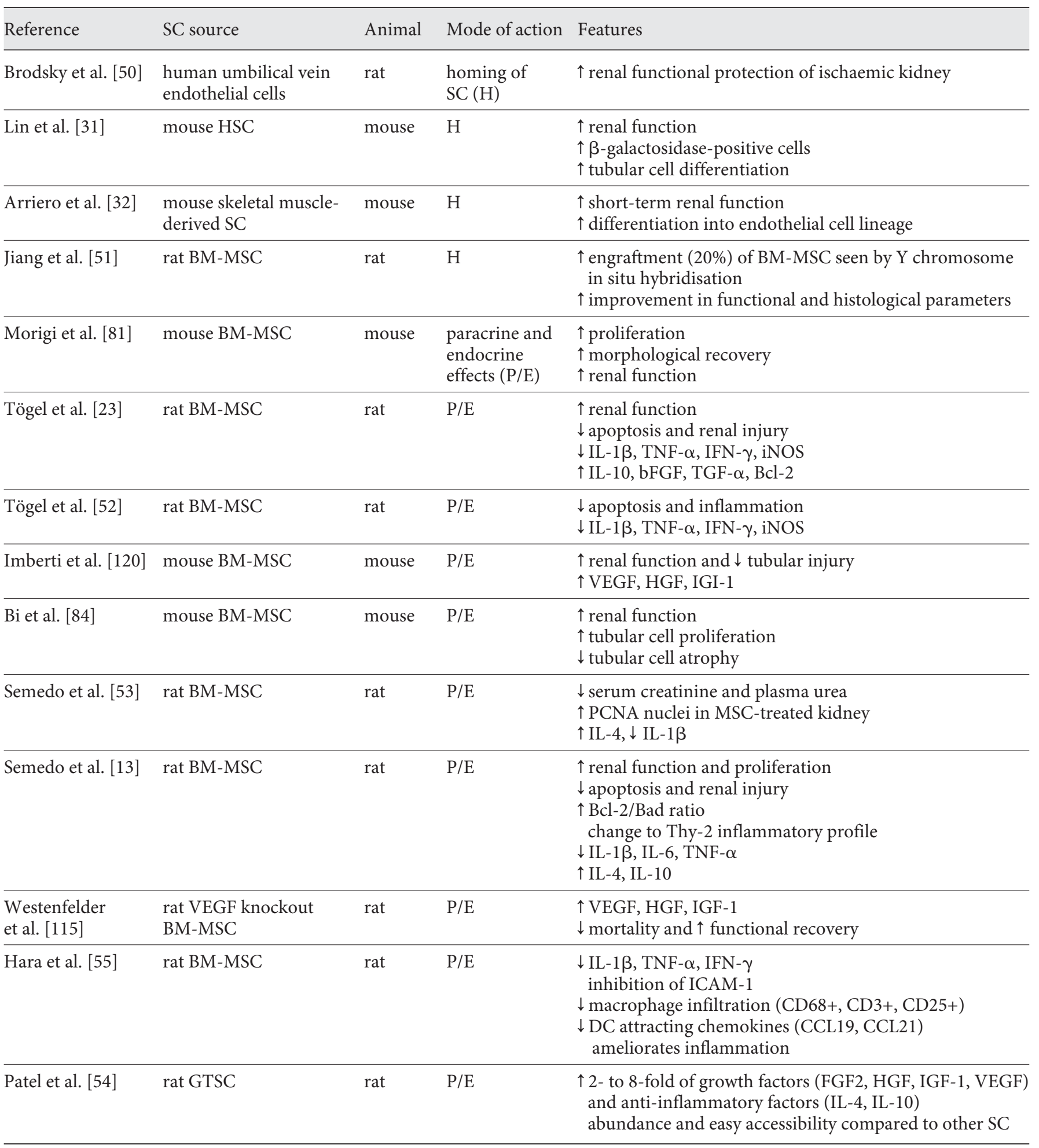

TGF- $\alpha=$ Transforming growth factor- $\alpha$ FGF2 = fibroblast growth factor 2 ; CD = cluster of differentiation; CCL $=$ lymphoid chemokines; iNOS = inducible nitric oxide synthase. 
Th2 profile [13]. In the rat model, improvement of renal function was followed by reduced expression of IL-6, IL$1 \beta$, TNF- $\alpha$ and an increased expression of IL- 4 and IL-10. The $\mathrm{Bcl} / \mathrm{Bcl}-2$-associated death promoter $(\mathrm{Bcl}-2 / \mathrm{Bad}) \mathrm{ra}-$ tio was increased in treated animals at $24 \mathrm{~h}$ after ischaemia [13]. AKI associated with renal tubular death is mediated by apoptosis which is regulated by members of $\mathrm{Bcl}-2$ family, and a decreased Bcl-2/Bad is favoured to cell death [13]. Hara et al. [55] showed that MSC application had a dose-dependent effect resulting in downregulation of proinflammatory cytokines (TNF- $\alpha$, IFN- $\gamma$, IL- $1 \beta$ ). The inhibition of adhesion molecules (intercellular adhesion molecule 1, ICAM-1) resulted in a diminished macrophage infiltration (cluster of differentiation 68, CD68+), CD3+ T cells and activated CD25+ cells and reduced dendritic cells (DC-) attracting chemokines (lymphoid chemokines, CCL19 and CCL21), resulting in a diminished infiltration of DCs $(\mathrm{Ox} 62+)$.

\section{Combined Effect (Paracrine + Homing; table 2)}

Wang et al. [56] in a rat model of IRI demonstrated that bone marrow mononuclear cells (BMMNC) led to a reduction of necrosis and apoptosis of renal tubular cells. This was due to an increase in cell proliferation due to differentiation of some transplanted BMMNC into renal tubular epithelial cells in addition to an increase in biological activity, due to release of various growth factors and trophic factors. Hagiwara et al. [57] similarly showed that using kallikrein-modified MSC (TK-MSC; combined SC and kallikrein gene approach) led to the migration and homing ability as well as paracrine effect, thereby enhanced renal protection and advanced benefits in healing the injured kidney. The expression of human tissue kallikrein in the rat kidney after TK-MSC implantation exhibited enhanced protection against renal injury by inhibiting apoptosis and inflammatory cell infiltration. Thus TK-MSC secreted recombinant human tissue kallikrein into culture medium and significantly improved stem cell survival during oxidative stress via activation of the phosphatidylinositol 3-kinases/protein kinase B (PI3K-Akt) pathway. At $48 \mathrm{~h}$ after IRI, TK-MSC inhibited interstitial neutrophil and monocyte/macrophage infiltration and decreased the myeloperoxidase activity, superoxide formation, p38 mitogen-activated protein kinase phosphorylation and expression of TNF- $\alpha$, monocyte chemoattractant protein-1 and ICAM-1 [57]. Wang et al. [58] showed improved renal function when SC of neural origin (neural precursor cells, NPC) were administered in the rat IRI model. The NPC were exclusively found in renal parenchyma, and treatment resulted in reduced proinflammatory IL-1 $\beta$ and TNF- $\alpha$ expression and increased IL- 4 and IL-10 transcription in addition to reduced macrophage infiltration. Similarly, Chen et al. [59] demonstrated that adipose-derived MSC (ADMSC) therapy minimised kidney injury after IRI by suppressing oxidative stress and inflammatory response. Furuichi et al. [12] also demonstrated a combined effect, where they were able to ameliorate induced AKI secondary to IRI with the use of ADMSC in a mouse model. The suppression of cytokines (IL-1 $\beta$ and TNF- $\alpha$ ) and chemokines (MIP-1 $\alpha$ ) led to an anti-inflammatory activity and alleviation of tubular necrosis. In this model, surprisingly homing occurred mostly in the lung, and they suggested that cell therapy may play a role in disease process like sepsis where multiple organs are involved.

Patschan et al. [60] targeted endothelial progenitor cells (EPCs), which are cells that have been documented to participate in postnatal neovascularisation (vasculogenesis) [60-66]. In their murine model of IRI, they demonstrated that in vitro Epac-1 Ac (exchange protein directly activated by cAMP-1 activator) pre-activation of EPCs did not increase overall expression intensity but induced a redistribution of $\beta_{1}$-integrins towards the cell membrane. They concluded that EPC pre-treatment with this integrin receptor activator augmented the anti-ischaemic potential of the cell and thus protected the kidney from acute IRI [60]. Huls et al. [67] demonstrated that either p-glycoprotein (P-GP) or breast cancer-resistant protein (BCRP) protected from AKI. In the mouse model of IRI, they demonstrated absence of renal damage when animals were transplanted with transporter-deficient bone marrow SC. They further concluded that bone marrow from P-GP- or BCRP-deficient mice contains significantly more monocytes and granulocytes as well as early outgrowth EPC which potentially fuel renal protection.

Stem cell plasticity is remarkable, and the broad plasticity is a possibility what determines the therapeutic potential for SC [68]. Wang et al. [58] suggested NPC treatment worked via influencing immunological responses, and describe that SC benefits are not tissue specific and thus show a direct link between neural molecules and renal protection. Orth et al. [69] have shown that growth and transcription factors similar to those essential to the nervous system operate in the kidney and are induced after an ischaemic episode. Shi et al. [70] support these findings. In their study, exogenous administration of glial cell-derived neurotrophic growth factor protected the kidney against IRI. Other research has shown neurospheres to produce growth factor [71] and cytokines [7275], thus modifying tissue immune responses. 
Table 2. Studies highlighting benefits of SC therapy in small animal models [combined paracrine/homing $(\mathrm{P} / \mathrm{H})$ and modified approaches (M)]

\begin{tabular}{|c|c|c|c|c|}
\hline Reference & SC source & Animal & Mode of action & Features \\
\hline Wang et al. [56] & BM-MNC mononuclear cells & rat & $\mathrm{P} / \mathrm{H}$ & $\begin{array}{l}\downarrow \text { apoptosis and necrosis } \\
\uparrow \text { differentiation into tubular epithelial cells in renal } \\
\text { parenchyma } \\
\uparrow \text { growth and trophic factors } \\
\downarrow \text { blood urea at } 24 \text { and } 48 \mathrm{~h}\end{array}$ \\
\hline Shi et al. [70] & $\begin{array}{l}\text { mouse kidney derived MSC } \\
\text { expressing glial cell line-derived } \\
\text { neurotropic factor }\end{array}$ & mouse & $\mathrm{P} / \mathrm{H}$ & $\begin{array}{l}\uparrow \text { homing in renal cortex } \\
\uparrow \text { nestin expression } \\
\downarrow \text { oxidative stress } \\
\uparrow \text { VEGF } \\
\uparrow \text { renal function } \\
\text { amelioration of IRI }\end{array}$ \\
\hline Hagiwara et al. [57] & $\begin{array}{l}\text { rat kallikrein-modified } \\
\text { MSC }\end{array}$ & rat & $\mathrm{P} / \mathrm{H}$ & $\begin{array}{l}\downarrow \text { apoptosis } \\
\downarrow \text { renal tubular injury } \\
\downarrow \text { serum creatinine and urea nitrogen } \\
\downarrow \text { tubular injury } \\
\downarrow \text { inflammatory cell infiltration }\end{array}$ \\
\hline Wang et al. [58] & rat NPC & rat & $\mathrm{P} / \mathrm{H}$ & $\begin{array}{l}\text { homing of NPC in renal parenchyma } \\
\downarrow \mathrm{IL}-1 \beta \text {, TNF- } \alpha \\
\uparrow \mathrm{IL}-10 \text {, IL- } 4 \\
\downarrow \text { macrophage infiltration } \\
\uparrow \text { improved renal function }\end{array}$ \\
\hline Patschan et al. [60] & murine EPC & mouse & $\mathrm{P} / \mathrm{H}$ & $\begin{array}{l}\text { preserved renal function ( } 35 \text {-min ischemia) } \\
\text { redistribution of } \beta_{1} \text {-integrin } \\
\text { homing of EPC in renal medulla }\end{array}$ \\
\hline Huls et al. [67] & $\begin{array}{l}\text { mouse BM-MSC } \\
\text { deficient in P-GP or } \\
\text { BCRP protein }\end{array}$ & mouse & $\mathrm{P} / \mathrm{H}$ & $\begin{array}{l}\uparrow \text { early outgrowth of EPC } \\
\uparrow \text { improved renal function (GFR and creatinine clearance) } \\
\downarrow \text { early inflammatory response } \\
20-30 \% \text { homing into renal parenchyma }\end{array}$ \\
\hline Chen et al. [59] & rat ADMSC & rat & $\mathrm{P} / \mathrm{H}$ & $\begin{array}{l}\downarrow \text { oxidative stress } \\
\downarrow \text { inflammatory response } \\
\downarrow \text { IL- } 1 \beta \text {, TNF- } \alpha \text {, IFN- } \gamma \\
\text { NFC-CFSE-positive cells homing in renal parenchyma } \\
\uparrow \text { IL-10, IL-4 }\end{array}$ \\
\hline Furuichi et al. [12] & mouse ADMSC & mouse & $\mathrm{P} / \mathrm{H}$ & $\begin{array}{l}\downarrow \text { cytokines (IL- } 1 \beta, \text { TNF- } \alpha, \text { IFN- } \gamma \text { ) and chemokines } \\
\quad \text { (MIP- } 1 \alpha \text { ) } \\
\downarrow \text { inflammatory activity } \\
\downarrow \text { tubular necrosis } \\
\text { distant homing in lung: possible benefit of use in clinical scenarios } \\
\text { like sepsis associated with multiorgan failure }\end{array}$ \\
\hline Nafar et al. [28] & $\begin{array}{l}\text { mouse BM-MSC + } \\
\text { GCSF }\end{array}$ & mouse & $\mathrm{M}$ & $\begin{array}{l}\downarrow \text { tubular necrosis } \\
\uparrow \text { renal function and histological recovery } \\
\uparrow \text { anti-apoptotic and anti-inflammatory factors } \\
\uparrow \text { angiogenic factor } \\
\uparrow \text { IL-10, hem-oxygenase- } 1 \text {, bone morphogenetic-7 } \\
\downarrow \text { IL- } 6 \text {, TGF- } \beta \text {, TNF- } \alpha\end{array}$ \\
\hline Tian et al. [96] & $\begin{array}{l}\text { mouse BM-MSC + } \\
\text { lipid mediator } \\
(14 S, 21 R-d i H D H A)\end{array}$ & mouse & M & $\begin{array}{l}\text { lipid mediator promotes MSC viability via PI3-AKT } \\
\text { signalling pathway } \\
\downarrow \text { serum creatinine and cell infiltration } \\
\downarrow \text { apoptosis and renal tubular cell death } \\
\downarrow \text { TNF- } \alpha \text { and reactive oxygen species } \\
\uparrow \text { HGF, IGF- } 1\end{array}$ \\
\hline Altun et al. [97] & $\begin{array}{l}\text { rat } \mathrm{BM}-\mathrm{MSC}+ \\
\mathrm{DPO}\end{array}$ & rat & M & $\begin{array}{l}\downarrow \text { serum creatinine and urea nitrogen } \\
\uparrow \text { histological recovery }\end{array}$ \\
\hline
\end{tabular}


Role of Resident Stem/Progenitor Cell Expansion and Proliferation

Following either ischaemic or toxic injury, the kidney has the potential to recover quickly [12]. This repair may be due to the surviving resident stem/progenitor cells undergoing epithelial cell spreading, cell de-differentiation and proliferation to cover the exposed area of the basement cell membrane [12]. The participation of integrins and cell adhesion molecules leads to repair; they are upregulated by stem cell therapy and in themselves represent regulators of migration, differentiation and proliferation. For example, release of HGF and IGF-1 can potentiate recovery of surviving cells and de-differentiation of tubule cells and their proliferation $[12,14,76]$. In addition, expression of differentiation factors like neural cell adhesion molecule and osteopontin leads tubular cells to re-differentiate and repolarise [12]. Administration of exogenous MSC led to alteration of all the IRI responses described above. Several studies have shown amelioration of various functional parameters $[13,23,30,77-83]$, and this is thought to be due to the paracrine/endocrine effects of MSC leading to an acceleration of regeneration of proximal tubular cells $[30,79,84]$. There is little evidence to support the hypothesis of transdifferentiation $[30,85,86]$. Recently Angelotti et al. demonstrated that $\mathrm{CD} 133+\mathrm{CD} 24+$ renal progenitors can differentiate into podocyte progenitors or tubular progenitors. These tubular committed progenitors display resistance to death, higher proliferation potential than other differentiated renal cells and regenerate into tubular cells following AKI. They concluded that the study provided further evidence of human renopoietic system and novel treatments could be aimed at promoting the regeneration capacity of these cells to prevent and treat tubular injury [87].

To add a further level of complexity, Nafar et al. [28] in a rat model of IRI administered MSC in addition to granulocyte colony-stimulating factor (GCSF), and were able to attenuate the recovery course of IRI as well as ameliorate tubular necrosis. They showed that GCSF works as a bone marrow stem cell mobilising cytokine which facilitates renal tubular regeneration; similar results were produced by Fang et al. [88]. Nafar et al. [28] evaluated these effects by measuring CD34+ cells in peripheral blood via flow cytometry, and demonstrated increased peripheral blood counts of the CD34+ cell lineage, thus suggesting that mobilisation of endogenous BMSCs may be an additional factor to SC playing a direct structural role or inserting paracrine/endocrine effects. Feng et al. [89] in a rat IRI model showed that administration of freshly isolated, uncultured, adipose tissue-derived SC (ADRC) significantly reduced mortality (survival: $100 \mathrm{vs.}$ $5 \%$; ADRC vs. control, respectively) and improved renal function (serum creatinine: $3.03 \pm 1.58$ vs. $7.32 \pm 2.32$; ADRC vs. control, respectively). In addition, they demonstrated a significant downregulation of the proinflammatory cytokines like chemokine (C-X-C motif) ligand 2 (CXCL2) and IL-6 (mRNA expression at $24 \mathrm{~h}$ following AKI). They demonstrated that ADRC enhance tubular cell proliferation as detected by an increase in ki-67-positive cells as early as $24 \mathrm{~h}$ following stem cell infusion, though the ADRC cells were found predominantly in the glomeruli and not the tubules.

Similarly, Kwon et al. [90] showed that recipient bone marrow-derived EPC (CD34+ EPC) and endothelial cells (CD146-positive EC) decreased in the circulation immediately following IRI. These cells were at this particular time point observed along the endothelial lining in peritubular capillaries in the ischaemic damaged kidney, and were not seen in their counterpart non-ischaemic controls. They suggested that the tissue regeneration maybe the result of proliferating surviving de-differentiated cells and renal SC, findings supported by other studies $[78,79,91]$. Kim et al. [92] concluded that intra-renal rodent cells have stem- or progenitor-like characteristics which contribute to the restoration of damaged tubular epithelial cells. Using 5-bromo-2'-deoxyuridine (BrdU)labelled slow cell cycle cells, they observed that BrdU-labelled cells were mainly located at either the junction of the cortex and outer medulla or the inner medulla. These BrdU-labelled cells not only survived IRI but thereafter proliferated and expressed functional tubule cell markers such as $\mathrm{Na} / \mathrm{K}$-ATPase, Na-K-Cl co-transporter-2 and aquaporin 1 and 2 . The beneficial effects of SC are thus further enhanced by generating a favourable environment created by administered SC where the resident stem/progenitor cell expansion and proliferation can take place and thus contribute to reduced injury [93-95].

\section{Modified Methods (SC and Additive Pharmacological} Agents; table 2)

Recently Tian et al. [96] developed a modified stem cell method, where they have shown that MSC enhanced by treatment with lipid mediator [14S,21R-dihydroxydocosahexaenoic acid (14S,21R-diHDHA)] further ameliorated IRI. The mice subjected to treated MSC showed reduced serum creatinine levels, reduced tubular cell death, inhibition of neutrophils, macrophages and DC infiltration within the kidney in addition to reduced TNF- $\alpha$ and reactive oxygen species levels. Treatment with 14S,21R- 
Table 3. Studies highlighting studies of SC therapy in large animal models

\begin{tabular}{|c|c|c|c|c|c|}
\hline Reference & SC source & Effect & Animal & Mode of action & Features \\
\hline $\begin{array}{l}\text { Zhen-Qiang et al. } \\
\text { [98] }\end{array}$ & $\begin{array}{l}\text { rabbit } \\
\text { BM-MSC }\end{array}$ & positive & rabbit & $\begin{array}{l}\text { Combined } \\
\text { paracrine/ } \\
\text { homing } \\
(\mathrm{P} / \mathrm{H})\end{array}$ & $\begin{array}{l}\uparrow \text { Bcl-2, Bcl-2-associated protein levels } \\
\uparrow \text { superoxide dismutase activity } \\
\uparrow \text { tissue regeneration in kidney } \\
\text { renal tubule homing of MSC } \\
\uparrow \text { recovery of renal function } \\
\downarrow \mathrm{TNF}-\alpha, \text { TGF- } \beta \text {, IL- } 1 \beta\end{array}$ \\
\hline Chade et al. [99] & $\begin{array}{l}\text { porcine autologous } \\
\text { EPC }\end{array}$ & positive & pig & $\mathrm{P} / \mathrm{H}$ & $\begin{array}{l}\uparrow \text { stromal-derived factor-1, angiopoietin- } 1 \text {, } \\
\text { Tie- } 2 \text {, c-kit expression and integrin- } \beta_{2} \\
\uparrow \text { and restored angiogenic activity, } \\
\text { improved microvascular density } \\
\uparrow \text { renal hemodynamics and function } \\
\downarrow \text { fibrosis } \\
\downarrow \text { oxidative stress }\end{array}$ \\
\hline Eirin et al. [100] & $\begin{array}{l}\text { porcine allogenic } \\
\text { ADMSC }\end{array}$ & positive & pig & $\mathrm{P} / \mathrm{H}$ & $\begin{array}{l}\uparrow \text { renal function } \\
\uparrow \text { and restored hemodynamics } \\
\downarrow \text { inflammation } \\
\downarrow \text { apoptosis } \\
\downarrow \text { oxidative stress } \\
\downarrow \text { microvascular loss and fibrosis }\end{array}$ \\
\hline $\begin{array}{l}\text { Brunswig- } \\
\text { Spickenheier et al. } \\
{[108]}\end{array}$ & $\begin{array}{l}\text { porcine allogeneic } \\
\text { MSC }\end{array}$ & negative & pig & $\mathrm{P} / \mathrm{H}$ & $\begin{array}{l}\text { inadequate immune-modulating effects } \\
\text { failed to inhibit the mixed lymphocyte reaction } \\
\uparrow \text { IL- } 6\end{array}$ \\
\hline
\end{tabular}

diHDHA thus promoted the viability of MSC in vivo through mechanism involving activation of PI3K/AKT signalling pathway and promoted secretion of renotrophic HGF and IGF-1, thereby rendering the cells resistant to apoptosis. Nafar et al. [28] administered MSC in addition to GCSF and were able to attenuate tubular necrosis. Altun et al. [97] in a rat model demonstrated that treatment with MSC and darbepoetin- $\alpha$ (DPO) concomitantly improved renal function when compared with the controls. Histological analysis demonstrated that tissue injury was significantly decreased in rats treated concomitantly with MSCs and DPO. These results suggest that concomitant application of SC and other pharmacological agents may be the potential novel renoprotective therapy for patients who have sustained an ischaemic renal insult.

\section{Large Animal Models and Role of Potential Stem Cell Benefits (table 3)}

Giraud et al. [1] recently published large animal model work. They showed benefits of porcine model over small animal models; the porcine model is a species which is characterised by human-like renal anatomic structure, multiparity and multilobular kidney. In addition, they can be used to create models which realistically simulate day-to-day practice human scenarios like DCD transplantation. Rodent models, though less expensive, have specific use and data extrapolation to a human situation is limited by anatomic and physiological differences. Zhen-Qiang et al. [98] published the beneficial effects of SC in a larger animal model using rabbits. Rabbits injected immediately after I/R with human bone morphogenic protein-7-transduced BM-MSCs showed a higher activity of superoxide dismutase, and a lower amount of malondialdehyde. The increased Bcl-2 and $\mathrm{Bcl}-2$-associated $\mathrm{X}$ protein levels indicated the regeneration of the kidney in the experimental group. Chade et al. [99] in an atherosclerotic renal artery stenosis (ARAS) model showed that pigs injected with autologous EPCs showed increased stromal derived factor-1, angiopoietin-1, Tie-2 and c-kit expression. In addition, the ARAS kidney itself releases c-kit-ligand stem cell factor and upregulated intergrin- $\beta_{2}$, suggesting activation of cor- 
responding homing signals. This relates to the injured kidney as to restored angiogenic activity, improved microvascular density, renal hemodynamics, function, decreased fibrosis and oxidative stress and attenuated endogenous injury signals.

Eirin et al. [100] showed that a single intrarenal delivery of labelled allogenic adipose tissue-derived MSC (isolated from a normal swine) into a pig subjected to ARAS restored the haemodynamics, renal function and reduced inflammation, apoptosis, oxidative stress, microvascular loss and fibrosis. These findings thus shed light not only onto the renoprotective mechanism (chronic injury models $[99,100])$, but also feasibility. The potential of such autologous and allogenic cell-based therapy can also be applied to scenarios of AKI (similar mechanisms), such as transplantation (where injury is anticipated). Further larger animal model studies are thus required to assess the effects of SC in renal ischaemia injury not only to assess efficiency but also safety, prior to translating research towards humans.

\section{Evidence Showing No Benefits of SC in Renal IRI}

Weissman et al. [101] demonstrated very little plasticity of HSC in mice following IRI, and concluded that differentiation of HSC to non-HSC does not occur in every animal model. Jiang et al. [102] in a mice model concluded that transplantation using HSCs or MSCs cell line did not improve the renal repair process. Similarly, Huls et al. [103] demonstrated that following IRI, approximately $10 \%$ of integrated tubular segments originated from transplanted bone marrow cells, but also showed that a significant decrease in creatinine clearance was observed at day 2 following ischaemia. This improved to normal levels on day 7 after ischaemia, similar to IRI damaged controls not receiving cell therapy. A mouse model developed by da Silva et al. [104] used BMSCs with or without FTY720 (a compound promoting preferential migration of lymphocytes to lymph nodes rather than to an inflammatory site), which did not demonstrate early kidney recovery following IRI. Similar findings were reported by Kale et al. [30] showing that injected BMSCs were not found in the kidney up to 3 weeks after administration, but 12 weeks later tubules contained 2-5\% BMSCs. This paper unfortunately did not quantify which bone marrow-derived SC were present (recipient or donor). No improvement was seen in renal function, and the authors concluded that the majority of tubule repair occurs probably via proliferation of endogenous renal cells rather than incorporation of BMSCs or by the protective factors secreted by these cells, findings later demonstrated by Lin et al. [93].

Duffield et al. [80] in a mouse model using an intravenous injection of bone marrow mesenchymal stromal cells demonstrated no evidence of differentiation into tubular cells indicating that BMSC do not contribute to restoration of epithelial integrity after an ischaemic insult. This was measured with cells expressing GFP, bacterial $\beta$-gal or harbouring male chromosome exclusively in these bone marrow-derived cells. This group also concluded tubule regeneration occurs by survival of de-differentiated epithelial cells which proliferate and re-differentiate into mature epithelial cells, as SC of bone marrow origin do not differentiate into renal cells [105]. De Broe [85] concluded that renal repair after acute ischaemic toxic injury seems to be limited to the kidney itself. Mechanism include the mobilisation of growth factors, stimulation of surviving de-differentiated cells, upregulation of protective proteins and recruiting SC localised deep in the kidney. They caution against the premature clinical use of bone marrow cells in treatment of renal failure and suggest that HSC mobilisation-associated granulocytosis may worsen renal failure.

Referring back to Giraud et al. [1] and advantages of large animal models, Behr et al. [106] published their results of an autologous large animal model (ovine). They summarised that the model was a relevant large animal model of kidney IRI providing a reliable setting for evaluation of MSC therapy. The MSC treatment did not exhibit reparative or paracrine properties (TNF- $\alpha$, VEGF$\alpha, \mathrm{Bcl}-2$, caspase-1), and no improvement was seen in renal function following $60 \mathrm{~min}$ of ischaemic damage. They concluded that there may be fundamental differences in species and stemness biology (stem cell turnover is remarkably higher in small animals than larger ones) [107], which make translation of results from rodent models to humans hazardous. Brunswig-Spickenheier et al. [108] in a porcine model contrary to their rat model demonstrated that porcine MSCs failed to inhibit the mixed lymphocyte reaction and induced robust production of proinflammatory IL-6. The authors concluded that MSCs exert inadequate immune-modulating effects and are not kidney protective (table 3).

\section{Potential Risk of Stem Cell Therapy}

Reinders et al. [22] highlight the possible risk associated with the use of SC therapy. For example, a patient treated with HSCs developed renal lesions which on ne- 
phrectomy were confirmed to be angiomyeloproliferative lesions, which were stem cell (HSC) derived or stem cell (HSC) induced [108]. The other concern they raised was lack of standardisation of these fresh cell products. The use of ESC (embryonic SC) is associated with a risk of malignant transformation and teratoma formation as seen with induced pluripotent stem (iPS) cells. iPS cells express Sox 2 and c-myc, and c-myc is an oncogene which may contribute to tumour genesis by overstimulation of cell growth or by causing genomic instability $[109,110]$. Reassuringly, Lee et al. [111] in rat model demonstrated improved renal function and survival and no evidence of tumour formation at 6 months, though 6 months may be a too short follow-up period. The risk of thrombosis and embolisation exists, and can worsen ischaemia and lead to potential end organ damage following intra-arterial administration of SC [112].

\section{Human Clinical Studies in AKI}

Patschan et al. [113] reported that sepsis is associated with significant impairment of EPC system. They showed increased EPC numbers, increased concentrations of proangiogenic mediators and reduced proliferation capacity of cells. In addition, the cohort of patients with acute renal dysfunction showed an even more pronounced elevation of CD133+/Flk+ cells, though average proangiogenic cytokines were not proportionally raised. Thus, acute renal dysfunction possibly activates 'vascular danger signals' in order to activate endogenous repair mechanisms, suggesting possible role of stem cell therapy with EPCs may improve the outcome in patients with sepsis and associated renal failure, in line with other studies [44, 112-114].

Westenfelder and Togel [115] address the role of allogeneic MSC in preventing and treating AKI following onpump coronary artery bypass graft or cardiac valve surgery with a suprarenal aortic infusion. They showed it to be safe and feasible; in addition, the MSC therapy prevented postoperative deterioration in renal function $(20 \%$ AKI incidence in case control), reduced the length of stay (40\%) and need for readmission (40\%) when compared to well-matched historical case controls [116-119]. The authors plan a double-blind, controlled, multicentre phase II efficacy study once late safety data are documented. They concluded that off-the-shelf use of allogenic MSC should thus be possible and safe as the MSC are hypoimmunogenic [do not express HLA-II (DR) and blood group antigens] $[25,115,117,118]$. They remain in the acutely injured kidney (and other organs) for a very short period of time, work via their paracrine and endocrine (VEGF, HGF, IGF-1) [25, 115, 117-121] modes of action and lack ectopic differentiation and oncogenic transformation.

Other documented phase I trials in the AKI situation include administration of MSC to kidney transplant recipients from living unrelated donors [122], patients with chronic allograft nephropathy, lupus nephritis currently conducted in China (Fuzhou Hospital) and for treatment of kidney transplant rejection in the Netherlands (Leiden University) (http://www.clinicaltrials.com) [116]. Tan et al. [122] in a randomised controlled trial demonstrated that in patients undergoing a live related renal transplant, the use of autologous MSC compared with anti-IL-2 receptor antibody induction therapy resulted in lower incidence of acute rejection, decreased risk of opportunistic infection, and better estimated renal function at 1 year. Patient and graft survival at 13-30 months was similar. This study unfortunately did not address the underlying mechanism, although short-term safety data are promising. Published data in a large animal model and human setting (safety, short-term and long-term) are still lacking.

\section{Conclusions}

Although the majority of studies in the field of renal IRI and stem cell therapy show remarkable benefits, they are mostly confined to small animal models. These results should be taken with caution and first translated to a large animal model such as the pig. Controversy exists regarding the exact mechanism, and thorough scientific exploration is required to assess mechanism, safety profile, reproducibility and methods to monitor administered SC.

Owing to the high morbidity and mortality associated with IRI/AKI and disappointing results from current available clinical therapeutic approaches, stem cell therapy may be promising, but it is imperative not to create unrealistic goals and possibly translate danger to patients.

\section{Disclosure Statement}

The authors have no conflicts of interest to disclose as described by the American Journal of Nephrology. 


\section{References}

$>1$ Giraud S, Favreau F, Chatauret N, Thuillier R, Maiga S, Hauet T: Contribution of large pig for renal ischemia-reperfusion and transplantation studies: the preclinical model. J Biomed Biotechnol 2011;2011:532127.

-2 Jang HR, Ko GJ, Wasowska BA, Rabb H: The interaction between ischemia-reperfusion and immune responses in the kidney. J Mol Med 2009;87:859-864.

-3 Sanchez-Fructuoso A, Marques M, Prats D, Barrientos A: Non-heart-beating donors: experience from the Hospital Clinico of Madrid. J Nephrol 2003;16:387-392.

-4 Koffman GK, Gambaro G: Renal transplantation from non heart beating donors: a review of the European experience. J Nephrol $2003 ; 16: 334-341$.

5 van der Woude FJ, Schnuelle P, Yard BA: Preconditioning strategies to limit graft immunogenicity and cold ischemic organ injury. J Investig Med 2004;52:323-329.

$\checkmark 6$ Wolfe RA, Asby VB, Milford EL, Ojo AO, Ettenger RE, Agodoa LY, Held PJ, Port FK: Comparison of mortality in all patients on dialysis, patients on dialysis awaiting transplantation, and recipients of a first cadaveric transplant. N Engl J Med 1999;341:17251730.

$>7$ Mollura DJ, Hare JM, Rabb H: Stem-cell therapy for renal diseases. Am J Kidney Dis 2003;42:891-905

$>8$ Meier-Kriesche H, Kaplan B: Waiting time on dialysis as the strongest modifiable risk factor for renal transplant outcomes: a paired donor kidney analysis. Transplantation 2002;74:1377-1381.

$>9$ Metcalfe M, Butterworth P, White S, Saunders R, Murphy G, Taub N, Veitch PS, Nicholson ML: A case control comparison of the results of renal transplantation from heartbeating and non heart-beating donors. Transplantation 2001;71:1556-1559.

$>10$ Castelao AM, Grino JM, Gonzalez C, Franco E, Gilvernet S, Andres E, Serón D, Torras J, Moreso F, Alsina J: Update of our experience in longterm renal function of kidneys transplanted from non-heart beating cadaveric donors. Transpl Proc 1993;25:1513-1515.

- 11 Nash K, Hafeez A, Hou S: Hospital-acquired renal insufficiency. Am J Kidney Dis 2002; 39:930-936.

12 Furuichi K, Shintani H, Sakai Y, Ochiya T, Matsushima K, Kaneko S, Wada T: Effects of adipose-derived mesenchymal cells on ischemia-reperfusion injury in kidney. Clin Exp Nephrol 2012;16:679-689.

$\checkmark 13$ Semedo P, Palasio CG, Oliveira CD, Feitoza CQ, Gonçalves GM, Cenedeze MA, Wang PM, Teixeira VP, Reis MA, Pacheco-Silva A, Câmara NO: Early modulation of inflammation by mesenchymal stem cell after acute kidney injury. Int Immunopharmacol 2009; 9:677-682.
14 Molitoris BA, Marrs J: The role of cell adhesion molecules in ischemic acute renal failure. Am J Med 1999;106:583-592.

15 Sáenz-Morales D, Escribese MM, Stamatakis K, García-Martos M, Alegre L, Conde E, Pérez-Sala D, Mampaso F, García-Bermejo ML: Requirements for proximal tubule epithelial cell detachment in response to ischemia: role of oxidative stress. Exp Cell Res 2006;312:3711-3727.

16 Boros P, Bromberg JS: New cellular and molecular immune pathways in ischemia/reperfusion injury. Am J Transplant 2006;6: 652-658.

17 Thurman JM: Triggers of inflammation after renal ischemia/reperfusion. Clin Immunol 2007;123:7-13.

18 Devarajan P: Update on mechanisms of ischemic acute kidney injury. J Am Soc Nephrol 2006;17:1503-1520.

19 Bonventre JV: Dedifferentiation and proliferation of surviving epithelial cells in acute renal failure. J Am Soc Nephrol 2003;14:S55S61.

20 Palevsky PM: Epidemiology of acute renal failure: the tip of the iceberg. Clin J Am Soc Nephrol 2006;1:6-7.

21 Schena FP: Role of growth factors in acute renal failure. Kidney Int Suppl 1998;66:S11S15.

22 Reinders ME, Rabelink TJ: Adipose tissuederived stem cells: can impure cell preparations give pure results? Nephrol Dial Transplant 2010;25:3874-3884.

23 Tögel F, Hu Z, Weiss K, Isaac J, Lange C, Westenfelder C: Administered mesenchymal stem cells protect against ischemic acute renal failure through differentiation-independent mechanisms. Am J Physiol Renal Physiol 2005;289:F31-F42.

24 Deng J, Kohda Y, Chiao H, Wang Y, Hu X, Hewitt SM, Miyaji T, McLeroy P, Nibhanupudy B, Li S, Star RA: Interleukin-10 inhibits ischemic and cisplatin-induced acute renal injury. Kidney Int 2001;60:2118-2128.

25 Humphreys BD, Bonventre JV: Mesenchymal stem cells in acute kidney injury. Annu Rev Med 2008;59:311-325.

26 Masereeuw R: Contribution of bone marrow-derived cells in renal repair after acute kidney injury. Minerva Urol Nefrol 2009;61: 373-384.

27 Bussolati B, Hauser PV, Carvalhosa R, Camussi G: Contribution of stem cells to kidney repair. Curr Stem Cell Res Ther 2009;4:2-8.

28 Nafar M, Parvin M, Sadeghi P, Ghoraishian M, Soleimani M, Tabibi A, Nouralizadeh A, Amirkhanlou S, Barzi F, Alipour B: Effects of stem cells and granulocyte colony stimulating factor in reperfusion injury. Iran J Kidney Dis 2010;4:207-213.

29 Rabb H: Paracrine and differentiation mechanisms underlying stem cell therapy for the damaged kidney. Am J Physiol Renal Physiol 2005;289:F29-F30.
30 Kale S, Karihaloo A, Clark PR, Kashgarian M, Krause DS, Cantley LG: Bone marrow stem cells contribute to repair of the ischemically injured renal tubule. J Clin Invest 2003; 112:42-49.

31 Lin F, Cordes K, Li L, Hood L, Couser WG, Shankland SJ, Igarashi P: Hematopoietic stem cells contribute to the regeneration of renal tubules after renal ischemia-reperfusion injury in mice. J Am Soc Nephrol 2003; 14:1188-1199.

32 Arriero M, Brodsky SV, Gealekman O, Lucas PA, Goligorsky MS: Adult skeletal muscle stem cells differentiate into endothelial lineage and ameliorate renal dysfunction after acute ischemia. Am J Physiol Renal Physiol 2004;287:F621-F627.

-33 Korbling M, Estrov Z: Adult stem cells for tissue repair - a new therapeutic concept? N Engl J Med 2003;349:570-582.

34 Bischoff R: Tissue culture studies on the origin of myogenic cell during muscle regeneration in the rat; in Mauro A, Bischoff R, Shafig SA, Carlson BM, Konigsberg I, Lipton B (eds): Muscle Regeneration. New York, Raven Press, 1979, pp 13-29.

35 Mauro A: Satellite cells of skeletal muscle fibers. J Biophys Biochem Cytol 1961;9:493495.

>36 Young HE, Steele TA, Bray RA, Detmer K, Blake LW, Lucas PW Jr, Black AC: Human pluripotent and progenitor cells display cell surface cluster differentiation markers CD10, CD13, CD56, and MHC class-I. Proc Soc Exp Biol Med 1999;221:63-71.

37 Young HE, Steele TA, Bray RA, Hudson J, Floyd JA, Hawkins K, Thomas K, Austin T, Edwards C, Cuzzourt J, Duenzl M, Lucas PA Jr, Black AC: Human reserve pluripotent mesenchymal stem cells are present in the connective tissues of skeletal muscle and dermis derived from fetal, adult, and geriatric donors. Anat Rec 2001;264:51-62.

38 Wise AF, Ricardo SD: Mesenchymal stem cells in kidney inflammation and repair. $\mathrm{Ne}$ phrology 2012;17:1-10.

39 Bajwa A, Kinsey GR, Okusa MD: Immune mechanisms and novel pharmacological therapies of acute kidney injury. Curr Drug Targets 2009;10:1196-1204.

40 Donovan P, Gearhart J: The end of the beginning for pluripotent stem cells. Nature 2001; 414:92-97.

41 Goodell M: Stem-cell 'plasticity': befuddled by the muddle. Curr Opin Hematol 2003;10: 208-213.

42 Herzog E, Chai L, Krause D: Plasticity of marrow-derived stem cells. Blood 2003;102: 3483-3493.

43 Weissman I: Stem cells: units of development, units of regeneration, and units of evolution. Cell 2000;100:157-168. 
-44 Balsam L, Wagers A, Christensen J, Kofidis T, Weissman I, Robbins R: Hematopoietic stem cells adopt mature hematopoietic fates in ischemic myocardium. Nature 2004;428: 668-673.

-45 Murry C, Soonpaa M, Reinecke H, Nakajima H, Rubar Mt, Pasumarthi K, Virag J, Bartelmez S, Poppa V, Bradford G, Dowell J, Williams D, Field L: Hematopoietic stem cells do not transdifferentiate into cardiac myocytes in myocardial infarcts. Nature 2004;428: 664-668.

46 Orlic D, Kajstura J, Chimenti S, Jakoniuk I, Anderson S, Li B, Pickel J, McKay R, NadalGinard B, Bodine D, Anversa P: Bone marrow cells regenerate infracted myocardium. Nature 2001;410:701-705.

-47 Pereira R, Halford K, O’Hara M, Leeper D, Sokolov B, Pollard M, Bagasra O, Prockop D: Cultured adherent cells from bone marrow can serve as long-lasting precursor cells for bone, cartilage, and lung in irradiated mice. Proc Natl Acad Sci (USA) 1995;92:48574861.

-48 Petersen B, Bowen W, Patrene K, Mars W, Sullivan A, Murase N, Boggs S, Greenberger J, Goff J: Bone marrow as a potential source of hepatic oval cells. Science 1999;284:11681170.

49 Raff M: Adult stem cell plasticity: fact or artifact? Annu Rev Cell Dev Biol 2003;19:1-22.

50 Brodsky S, Kim B, Yamamoto T, Tada T, Goligorsky M: Endothelial dysfunction in acute renal ischemia: rescue by transplanted endothelial cells. Am J Physiol Renal Physiol 2002;282:F1140-F1149.

-51 Jiang H, Qu L, Li Y, Gu L, Shi Y, Zhang J, W Zhu, Li J: Bone marrow mesenchymal stem cells reduce intestinal ischemia/reperfusion injuries in rats. J Surg Res 2011;168:127-134.

-52 Togel F, Weiss K, Yang Y, Hu Z, Zhang P, Westenfelder C: Vasculotropic, paracrine actions of infused mesenchymal stem cells are important to the recovery from acute kidney injury. Am J Physiol Renal Physiol 2007; 292:F1626-F1635.

-53 Semedo P, Wang PM, Andreucci TH, Cenedeze MA, Teixeira VPA, Reis MA, PachecoSilva A, Câmara NOS: Mesenchymal stem cells ameliorate tissue damages triggered by renal ischemia and reperfusion injury. Transplant Proc 2007;39:421-423.

54 Patel J, Pancholi N, Gudehithlu KP, Sethupathi P, Hart PD, Dunea G, Arruda JAL, Singh AK: Stem cells from foreign body granulation tissue accelerate recovery from acute kidney injury. Nephrol Dial Transplant 2012;27:1780-1786.

55 Hara Y, Stolk M, Ringe J, Dehne T, Ladhoff J, Kotsch K, Reutzel-Selke A, Reinke P, Volk $\mathrm{HD}$, Seifert M: In vivo effect of bone marrow-derived mesenchymal stem cells in a rat kidney transplantation model with prolonged cold ischemia. Transpl Int 2011;24: 1112-1123.
6 Wang Y, Hu F, Wang ZJ, Wang GX, Zhang $\mathrm{ZH}$, Xie P, CP Cui: Administration of bone marrow-derived stem cells suppresses cellular necrosis and apoptosis induced by reperfusion of ischaemic kidneys in rats. Chin Med J 2008;121:268-271.

57 Hagiwara M, Shen B, Chao L, Chao J: Kallikrein-modified mesenchymal stem cell implantation provides enhanced protection against acute ischemic kidney injury by inhibiting apoptosis and inflammation. Hum Gene Ther 2008;19:807-819.

58 Wang PH, Schwindt TT, Barnabé GF, Motta FL, Semedo P, Beraldo FC, Mazzali M, Dos Reis MA, Teixeira Vde P, Pacheco-Silva A, Mello LE, Câmara NO: Administration of neural precursor cells ameliorates renal ischemia-reperfusion injury. Nephron Exp Nephrol 2009;112:e20-e28.

59 Chen Y, Sun C, Lin Y, Chang L, Chen Y, Tsai T, Chung S, Chua S, Kao Y, Yen C, Shao P, Chang K, Leu S, Yip H: Adipose-derived mesenchymal stem cell protects kidneys against ischemia-reperfusion injury through suppressing oxidative stress and inflammatory reaction. J Transl Med 2011;9:51.

60 Patschan D, Patschan S, Wessels JT, Becker JU, David S, Henze E, Goligorsky MS, Müller GA: Epac-1 activator 8-O-cAMP augments renoprotective effects of allogeneic murine EPCs in acute ischemic kidney injury. Am J Physiol Renal Physiol 2010;298:F78-F85.

61 Asahara T, Masuda H, Takahashi T, Kalka C, Pastore C, Silver M, Kearne M, Magner M, Isner JM: Bone marrow origin of endothelial progenitor cells responsible for postnatal vasculogenesis in physiological and pathological neovascularization. Circ Res 1999;85: 221-228.

62 Asahara T, Murohara T, Sullivan A, Silver M van der Zee R, Li T, Witzenbichler B, Schatteman G, Isner JM: Isolation of putative progenitor endothelial cells for angiogenesis. Science 1997;275:964-967.

63 Khakoo AY, Finkel T: Endothelial progenitor cells. Annu Rev Med 2005;56:79-101.

64 Schuster MD, Kocher AA, Seki T, Martens TP, Xiang G, Homma S, Itescu S: Myocardial neovascularization by bone marrow angioblasts results in cardiomyocyte regeneration. Am J Physiol Heart Circ Physiol 2004; 287:H525-H532.

65 Urbich C, Dimmeler S: Endothelial progenitor cells functional characterization. Trends Cardiovasc Med 2004;14:318-322.

66 Urbich C, Dimmeler S: Endothelial progenitor cells: characterization and role in vascular biology. Circ Res 2004;95:343-353.

67 Huls M, Schoeber JP, Verfaillie CM, Luttun A, Ulloa-Montoya F, Menke AL, van Bolderen LR, Woestenenk RM, Merkx GF, Wetzels JF, Russel FG, Masereeuw R: Deficiency of either p-glycoprotein or breast cancer resistance protein protect against acute kidney injury. Cell Transplant 2010;19:1195-1208.
68 Azizi SA, Stokes D, Augelli BJ, DiGirolamo C, Prockop DJ: Engraftment and migration of human bone marrow stromal cells implanted in the brains of albino rats - similarities to astrocyte grafts. Proc Natl Acad Sci USA 1998;95:3908-3913.

69 Orth SR, Ritz E, Suter-Crazzolara C: Glial cell line-derived neurotrophic factor (GDNF) is expressed in the human kidney and is a growth factor for human mesangial cells. Nephrol Dial Transplant 2000;15:589595.

70 Shi H, Patschan D, Dietz GP, Bähr M, Plotkin M, MS Goligorsky MS: Glial cell line-derived neurotrophic growth factor increases motility and survival of cultured mesenchymal stem cells and ameliorates acute kidney injury. Am J Physiol Renal Physiol 2008; 294:F229-F235.

71 Einstein O, Ben-Menachem-Tzidon O, Mizrachi-Kol R, Reinhartz E, Grigoriadis N, Ben-Hur T: Survival of neural precursor cells in growth factor-poor environment: implications for transplantation in chronic disease. Glia 2006;53:449-455.

72 Ben-Hur T: Immunomodulation by neural stem cells. J Neurol Sci 2008;265:102-104.

73 Pluchino S, Zanotti L, Rossi B, Brambilla E, Ottoboni L, Salani G, Martinello M, Cattalini A, Bergami A, Furlan R, Comi G, Constantin, Martino G: Neurosphere-derived multipotent precursors promote neuroprotection by an immunomodulatory mechanism. Nature 2005;436:266-271.

- 74 Sheng WS, Hu S, Ni HT, Rowen TN, Lokensgard JR, Peterson PK: TNF-alpha-induced chemokine production and apoptosis in human neural precursor cells. J Leukoc Biol 2005;78:1233-1241.

75 Zheng XS, Yang XF, Liu WG, Pan DS, Hu WW, Li G: Transplantation of neural stem cells into the traumatized brain induces lymphocyte infiltration. Brain Inj 2007;21:275278

76 Palevsky PM: Epidemiology of acute renal failure: the tip of the iceberg. Clin J Am Soc Nephrol 2006;1:6-7.

77 Baud L, Haymann JP, Bellocq A, Fouqueray B: Contribution of stem cells to renal repair after ischemia/reperfusion. Bull Acad Natl Med 2005;189:635-643.

-78 Poulsom R, Forbes SJ, Hodivala-Dilke K, Ryan E, Wyles S, Navaratnarasah S: Bone marrow contributes to renal parenchymal turnover and regeneration. J Pathol 2001; 195:229-235.

-79 Gupta S, Verfaillie C, Chmielewski D, Kim Y, Rosenberg ME: A role for extra-renal cells in the regeneration following acute renal failure. Kidney Int 2002;62:1285-1290.

80 Duffield JS, Park KM, Hsiao LL, Kelley VR, Scadden DT, Ichimura T: Restoration of tubular epithelial cells during repair of the post-ischemic kidney occurs independently of bone marrow-derived stem cells. J Clin Invest 2005;115:1743-1755. 
81 Morigi M, Imberti B, Zoja C, Corna D, Tomasoni S, Abbate M: Mesenchymal stem cells are renotropic, helping to repair the kidney and improve function in acute renal failure. J Am Soc Nephrol 2004;15:1794-804.

-82 Morigi M, Benigni A, Remuzzi G, Imberti B: The regenerative potential of stem cells in acute renal failure. Cell Transplant 2006; 1:S111-S117.

-83 Humphreys BD, Duffield JD, Bonventre JV: Renal stem cells in recovery from acute kidney injury. Minerva Urol Nefrol 2006;58: 329-337.

- 84 Bi B, Schmitt R, Israilova M, Nishio H, Cantley LG: Stromal cells protect against acute tubular injury via an endocrine effect. J Am Soc Nephrol 2007;18:2486-2496.

$\$ 85$ De Broe ME: Tubular regeneration and the role of bone marrow cells: 'stem cell therapy' - a panacea? Nephrol Dial Transplant 2005;20:2318-2320.

86 Humphreys BD, Bonventre JV: The contribution of adult stem cells to renal repair. Nephrol Ther 2007;3:3-10.

-87 Angelotti ML, Ronconi E, Ballerini L, Peired A, Mazzinghi B, Sagrinati C, Parente E, Gacci M, Carini M, Rotondi M, Fogo AB, Lazzeri E, Lasagni L, Romagnani P: Characterization of renal progenitors committed toward tubular lineage and their regenerative potential in renal tubular injury. Stem Cells 2012; 30:1714-1725.

-88 Fang TC, Alison MR, Cook HT, Jeffery R, Wright NA, Poulsom R: Proliferation of bone marrow-derived cells contributes to regeneration after folic acid-induced acute tubular injury. J Am Soc Nephrol 2005; 16: 1723-1732.

-89 Feng Z, Ting J, Alfonso Z, Strem BM, Fraser JK, Rutenberg J, Kuo HC, Pinkernell K: Fresh and cryopreserved, uncultured adipose tissue-derived stem and regenerative cells ameliorate ischemia-reperfusion-induced acute kidney injury. Nephrol Dial Transplant 2010;25:3874-3884.

\$0 Kwon O, Miller S, Li N, Khan A, Kadry Z, Uemura T: Bone marrow-derived endothelial progenitor cells and endothelial cells may contribute to endothelial repair in the kidney immediately after ischemia-reperfusion. J Histochem Cytochem 2010;58:687-694.

-91 Oliver JA, Maarouf O, Cheema FH, Martens $\mathrm{TP}, \mathrm{Al}$-Awqati Q: The renal papilla is a niche for adult kidney stem cells. J Clin Invest 2004;114:795-804.

92 Kim J, Kim JI, Na YK, YM Park YM: Intrarenal slow cell-cycle cells contribute to the restoration of kidney tubules injured by ischemia/reperfusion. Anat Cell Biol 2011;44: 186-193.

-93 Lin F, Moran A, Igarashi P: Intrarenal cells, not bone marrow-derived cells, are the major source for regeneration in postischemic kidney. J Clin Invest 2005;115:1756-1764.
94 Chen J, Park HC, Addabbo F: Kidney-derived mesenchymal stem cells contribute to vasculogenesis, angiogenesis and endothelial repair. Kidney Int 2008;74:879-889.

$\checkmark 95$ Sagrinati C, Ronconi E, Lazzeri E: Stem-cell approaches for kidney repair: choosing the right cells. Trends Mol Med 2008;14:277285.

-96 Tian H, Lu Y, Shah SP, Wang Q, Hong S: 14S, 21R-dihydroxy-docosahexaenoic acid treatment enhances mesenchymal stem cell amelioration of renal ischemia/reperfusion injury. Stem Cells Dev 2012;21:1187-1199.

97 Altun B, Yilmaz R, Aki T, Akoglu H, Zeybek D, Piskinpasa S, Uckan D, Purali N, Korkusuz P, Turgan C: Use of mesenchymal stem cells and darbepoetin improve ischemia-induced acute kidney injury outcomes. Am J Nephrol 2012;35:531-539.

$\$ 98$ Zhen-Qiang F, Bing-Wei Y, Yong-Liang L, Xiang-Wei W, Shan-Hong Y, Yuan-Ning Z, Wei-Sheng J, Wei C, Ye G: Localized expression of human BMP-7 by BM-MSCs enhances renal repair in an in vivo model of ischemia-reperfusion injury. Genes Cells 2012;17:53-64.

99 Chade AR, Zhu XY, Krier JD, Jordan KL, Textor SC, Grande JP, Lerman A, Lerman LO: Endothelial progenitor cells homing and renal repair in experimental renovascular disease. Stem Cells 2010;28:10391047.

100 Eirin A, Zhu XY, Krier JD, Tang H, Jordan KL, Grande JP, Lerman A, Textor SC, Lerman LO: Adipose tissue-derived mesenchymal stem cells improve revascularization outcomes to restore renal function in swine atherosclerotic renal artery stenosis. Stem Cells 2012;30:1030-1041.

101 Wagers AJ, Sherwood RI, Christensen JL, Weissman IL: Little evidence for developmental plasticity of adult hematopoietic stem cells. Science 2002;297:2256-2259.

102 Jiang Y, Jahagirdar BM, Reinhardt RL, Schwartz RE, Keene CD, Ortiz-Gonzalez XR, Reyes M, Lenvik T, Lund T, Blackstad M, Du J, Aldrich S, Lisberg A, Low WC, Largaespada DA, Verfaillie CM: Pluripotency of mesenchymal stem cells derived from adult marrow. Nature 2012;418:41-49.

103 Huls M, Russel FGM, Masereeuw R: Insights into the role of bone marrow-derived stem cells in renal repair. Kidney Blood Press Res 2008;31:104-110.

104 da Silva LB, Palma PV, Cury PM, Bueno V: Evaluation of stem cell administration in a model of kidney ischemia-reperfusion injury. Int Immunopharmacol 2007;7:16091616.

105 Duffield JS, Bonventre JV: Kidney tubular epithelium is restored without replacement with bone marrow-derived cells during repair after ischemic injury. Kidney Int 2005; 68:1956-1961.
106 Behr L, Hekmati M, Lucchini A, Houcinet K, Faussat AM, Borenstein N, Noel LH, Lelievre-Pegorier M, Laborde K: Evaluation of the effect of autologous mesenchymal stem cell injection in a large-animal model of bilateral kidney ischaemia reperfusion injury. Cell Prolif 2009;42:284-297.

107 Wagner JL, Storb R: Preclinical large animal models for hematopoietic stem cell transplantation. Curr Opin Hematol 1996; 3:410-415.

108 Brunswig-Spickenheier B, Boche J, Westenfelder C, Peimann F, Gruber AD, Jaquet K, Krause K, Zustin J, Zander AR, Lange C: Limited immune-modulating activity of porcine mesenchymal stromal cells abolishes their protective efficacy in acute kidney injury. Stem Cells Dev 2010;19:719729.

109 Thirabanjasak D, Tantiwongse K, Thorner PS: Angiomyeloproliferative lesions following autologous stem cell therapy. J Am Soc Nephrol 2010;21:1218-1222.

110 Pelengaris S, Khan M, Evan G: c-MYC: more than just a matter of life and death. Nat Rev Cancer 2002;2:764-776.

111 Lee PY, Chien Y, Chiou GY, Lin CH, Chiou SH, Tarng DC: Induced pluripotent stem cells without c-Myc attenuate acute kidney injury via down-regulating the signaling of oxidative stress and inflammation in ischemia-reperfusion rats. Cell Transplant 2012, Epub ahead of print.

- 112 Kawahara T, Kin T, Kashkoush S, Gala-Lopez B, Bigam DL, Kneteman NM: Portal vein thrombosis is a potential preventable complication in clinical islet transplantation. Am J Transplant 2011;11:2700-2777.

113 Patschan SA, Patschan D, Temme J, Korsten P, Wessels JT, Koziolek M, Henze E, Müller GA: Endothelial progenitor cells (EPC) in sepsis with acute renal dysfunction (ARD). Crit Care 2011;15:R94.

114 Patschan D, Krupincza K, Patschan S, Zhang Z, Hamby C, Goligorsky MS: Dynamics of mobilization and homing of endothelial progenitor cells after acute renal ischemia: modulation by ischemic preconditioning. Am J Physiol Renal Physiol 2006; 291:F176-F185.

115 Westenfelder C, Togel FE: Protective actions of administered mesenchymal stem cells in acute kidney injury: relevance to clinical trials. Kidney Int Suppl 2011;1:103106.

116 Patschan D, Patschan S, Gobe GG, Chintala S, Goligorsky MS: Uric acid heralds ischemic tissue injury to mobilize endothelial progenitor cells. J Am Soc Nephrol 2007;18:1516-1524. 
117 Gooch A, Doty J, Flores J, Swenson L, Toegel FE, Reiss GR, Lange C, Zander AR, $\mathrm{Hu}$ Z, Poole S, Ping Zhang P, Westenfelder C: Initial report on a phase I clinical trial: prevention and treatment of post-operative acute kidney injury with allogeneic mesenchymal stem cells in patients who require on-pump cardiac surgery. Cell Ther Transplant 2008;1:31-35.

118 Tögel FE, Westenfelder C: Mesenchymal stem cells: a new therapeutic tool for AKI. Nat Rev Nephrol 2010;6:179-183.
119 Tögel F, Cohen A, Zhang P, Yang Y, Hu Z, Westenfelder C: Autologous and allogeneic marrow stromal cells are safe and effective for the treatment of acute kidney injury. Stem Cells Dev 2009;18:475-485.

120 Imberti B, Morigi M, Tomasoni S, Rota C, Corna D, Longaretti L, Rottoli D, Valsecchi F, Benigni A, Wang J, Abbate M, Zoja C, Remuzzi G: Insulin-like growth factor-1 sustains stem cell mediated renal repair. J Am Soc Nephrol 2007;18:2921-2928.
121 Tögel F, Zhang P, Hu Z, Westenfelder C: VEGF is a mediator of the renoprotective effects of multipotent marrow stromal cells in acute kidney injury. J Cell Mol Med 2009; 13:2109-2114.

122 Tan J, Wu W, Xu X, Liao L, Zheng F, Messinger S, Sun X, Chen J, Yang S, Cai J, Gao X, Pileggi A, Ricordi C: Induction therapy with autologous mesenchymal stem cells in living-related kidney transplants: a randomized controlled trial. JAMA 2012;307: 1169-1177. 